\title{
Investigating Teacher's Professional Life Quality Levels in Terms of the Positive Psychological Capital
}

\author{
Sinan Yalçın ${ }^{1} \&$ İsa Y. İsgör ${ }^{2}$ \\ ${ }^{1}$ Education Management Department, Education Science Department, Faculty of Education, Erzincan University, \\ Turkey \\ ${ }^{2}$ Psychological Counseling And Guidance Department, Education Science Department, Faculty of Education, \\ Erzincan University, Turkey \\ Correspondence: Education Management Department, Education Science Department, Faculty of Education, \\ Erzincan University, Turkey. E-mail: sinan29@gmail.com
}

Received: January 28, 2017

Accepted: March 11, 2017

Online Published: April 11, 2017

doi:10.5539/ies.v10n5p1

URL: https://doi.org/10.5539/ies.v10n5p1

\begin{abstract}
This study, which investigated the relationship between teachers' professional life qualities and positive psychological capital, was designed in a relational screening pattern in the quantitative research method. Teachers, who worked in primary, secondary and high school in Erzincan city centre of Turkey in 2014-2015 academic year, participated in the research. The study group consisted of totally 182 teachers selected by random sampling method from the research field. The research data were collected through two different scales as "Professional Life Quality" and "Positive Psychological Capital". The obtained data were subjected to frequency, arithmetic mean, and correlation and regression analysis with SPSS 22 program. According to the results obtained from the research, it was found out that the positive psychological capital levels and quality of professional lives of teachers were high. According to the results of the study, it was noticed that there was a significant positive correlation between the teachers' professional life qualities and positive psychological capital levels. Another result obtained from the research was that teachers' professional life qualities were a significant predictor on their positive psychological capitals.
\end{abstract}

Keywords: professional life quality, positive psychological capital, teacher

\section{Introduction}

Today, the fact that the most important element determining the organizational success in the management understanding of organizations is the human resource is accepted by the administrative stages of the management scientists and organizations. Considering this fact, the professional environment of the human resource, the quality of work, the psychological, spiritual and academic supports provided to the employees has been the most discussed and researched topic at present. Employees spend most of their times in their professional environments and activities related to their works. As the employees spend a large part of their time in their professional environments, factors such as the nature of the profession, the suitability of the professional environment, and the pleasure of the employee are the antagonistic factors that determine the efficiency and effectiveness of the employees.

All these facts revealed the concept of professional life quality. The ability of organizations to survive in a competitive environment depends on their ability to carry out their objectives of being able to carry on with their assets, in other words, their ability to be effective and productive. Employees are among the most important elements that make the organizations effective. It can be claimed that, in addition to the high professional life quality in the organizational life of employees, employee happiness may affect many factors such as their motivations for the goals and targets and employees' associative loyalty.

\subsection{Professional Life Quality}

Nowadays, clearly realizing that the determinant element of organizational performance is the "workers" emphasized the concept of the professional life quality and increased the importance of the applications in this topic. The creativity potential of workers is a fundamental source of competitive superiority of the organizations. The best way to use this source is to provide a high quality business and living environment. The increase in the 
qualifications of workers and accordingly the increase in expectation direct the organizations to the decisions and practices that will improve the professional life quality (Barutçugil, 2004).

The professional life quality is a technique that aims to improve the quality of life by making changes in the current working environment, increase the quality of the individuals working in the organization while increasing the efficiency of the organization and to achieve their satisfaction by aiming to make better working conditions (Erginer, 2003). Professional life quality is a management philosophy that aims to provide employees with better working conditions in the institution they are working, relieves employees a sense of management physically and psychologically and raises the value of all employees of the organization (Yücetürk, 2005). In other words, professional life quality can also be defined as the increase in the satisfaction of employees at work.

With the establishment of the professional life quality, productivity and effectiveness are increased on the one hand, while a suitable environment is prepared for the employees on the other hand. In this sense, it is very important to improve the quality of teachers' professional lives in the education system. Because improving the quality of teachers' professional lives is not only about the teachers, but also about the future of their students, parents, society, and all the country.

\subsection{Positive Psychological Capital}

Achieving the organizational success is not possible only with financial and physical capital. However, organizational success will be achieved by increasing employee performance, motivation, institutional commitment, job satisfaction, and motivation. For this, the psychological conditions of the employees should be tried to be improved, the opportunities for the emergence of existing capacities should be provided and their characteristics and abilities should be improved (Uğurlu-Kara, 2014).

Among the factors affecting the behaviour of individuals in their professional lives, the emotional experiences of the employees have great significance as well as the individual characteristics of the employees and the quality of the work, the working environment and their characteristics. Changes and fluctuations in the emotional experiences of employees affect the behaviour and motivation of individuals in their professional lives. In this sense, there are some effects on the professional lives of the individuals such as; the individual's organizational affiliation and organizational life, emotional characteristics of employees, emotional experiences in business life, and the emotional events they had that day or experienced in the past (Özdevecioğlu, 2004).

Psychological capital can be defined as a set of characteristics that can be changed and developed by experience or education, in particular for the development and direction of personal and organizational performance (Luthans, 2002).

Increasing competition in today's professional life and widespread professional recognition based on the human make worker productivity and contributions to the organizations more important every day. In this context, unlike the traditional viewpoint, positive psychology and positive organizational behaviour give more attention to the individual improvement in productivity and performance increase employees, and will contribute more if their level of psychological well-being is high (Erkuş \& Findıkl1, 2013).

In the professional life, focusing only on the negative aspects of behaviours that employees demonstrate and emphasizing the negative sides of each result, perceiving the professional life as problems and the loss of employees in these problems made things even more complicated. As there are not only negative aspects of life, there are no circumstances, which can be considered as absolutely negative, in a task in the working life, neither in the fulfilment of a responsibility nor in the results obtained. Somehow, this is related to one's point of view. Some employees are productive, qualified, and innovative and tend to be part of change. Employees can now become producers of positive situations and can move on to become happy and healthy individuals. Positive psychology focuses on the mentioned good sides, apart from the problems of the individuals. Considering this fact, positive psychology knowledge contributes to organizations in having features that make individuals more effective (Erkmen and Esen, 2012).

Psychological qualities that best explain psychological capital structure are suggested to be hope, psychological endurance, optimism and self-sufficiency (Luthans, 2002). In the scale developed by Tösten and Özgan (2014), it was dealt with the characteristics of the psychological endurance, optimism, self-efficacy, confidence, and extroversion. In this study, the six characteristics of the psychological capital are discussed.

In this research, it is desired to investigate the relationship between teachers' positive psychological capital levels and professional life qualities. For this purpose, the problem sentence and sub-problems were determined as follows. 


\subsection{Problem Sentence}

What is the relationship between the qualities of teachers' professional lives and positive psychological capital?

\subsubsection{Sub-Problems}

1) How are the levels of teachers' professional life qualities?

2) How are the levels of teachers' positive psychological capital levels?

3) What is the relationship between the teachers' professional life qualities and positive psychological capital?

4) Are the teachers' professional life qualities a meaningful predictor of their positive psychological capital?

\section{Method}

As it was aimed in this study to determine the relationships between the positive psychological capital levels and professional life quality of the teachers, correlational research design was used. Correlational research is defined as "a research model which aims to determine the correlations between two or more variables (Karasar, 2012).

\subsection{Research Group}

Teachers, who worked in primary, secondary, and high school in Erzincan city centre of Turkey in 2014-2015 academic years, participated in the research. The study group consisted of totally 182 teachers selected by random sampling method from the research field. The demographic information of the sample of the survey is presented in Table 1 below.

Table 1. The demographic information of the sample of the survey

\begin{tabular}{|c|c|c|c|c|c|c|c|}
\hline Options & & 1 & 2 & 3 & 4 & 5 & Total \\
\hline \multirow{3}{*}{ Gender } & & Male & Female & & & & - \\
\hline & $\eta$ & 84 & 98 & & & & 182 \\
\hline & $\%$ & 46.2 & 53.8 & & & & 100 \\
\hline \multirow{3}{*}{ Education Level } & & Undergrad. & Graduate & & & & - \\
\hline & $\eta$ & 159 & 23 & & & & 182 \\
\hline & $\%$ & 87.4 & 12.6 & & & & 100 \\
\hline \multirow{3}{*}{ Marriage Status } & & Married & Single & & & & - \\
\hline & $\eta$ & 135 & 47 & & & & 182 \\
\hline & $\%$ & 74.2 & 25.8 & & & & 100 \\
\hline \multirow{3}{*}{ Seniority } & & $1-5$ & $6-10$ & $11-15$ & $16-20$ & \multirow{3}{*}{$\begin{array}{c}21- \\
8 \\
4.4\end{array}$} & \\
\hline & $\eta$ & 92 & 36 & 26 & 20 & & 182 \\
\hline & $\%$ & 50.5 & 19.8 & 14.3 & 11 & & 100 \\
\hline \multirow{3}{*}{ School Type } & & Primary & Secondary & High Sc. & & & \\
\hline & $\eta$ & 60 & 49 & 73 & & & 182 \\
\hline & $\%$ & 33 & 26.9 & 40.1 & & & 100 \\
\hline \multirow{3}{*}{$\begin{array}{l}\text { Average } \\
\text { Period }\end{array}$} & & $1-3$ & $4-6$ & $7-10$ & $10-$ & & \\
\hline & $\eta$ & 129 & 24 & 15 & 14 & & 182 \\
\hline & $\%$ & 70.9 & 13.2 & 8.2 & 7.7 & & 100 \\
\hline
\end{tabular}

\subsection{Research Model}

The research is a study in the relational model to determine the level of teachers' professional life qualification levels of positive psychological capital.

\subsection{Data Collection Tools}

Three measurement tools were used to collect the research data. These measurement tools were the Personal Information Form developed by researchers, Positive Psychological Capital Scale (Tösten, 2015), and the Professional Life Quality Scale developed by Erdem (2008) (PLQ).

\subsubsection{Personal Information Form}

It was developed by the researchers to collect socio-demographic data. It is a form that includes questions to determine the variables such as: gender, school type, field, class, achievement average, education level of parents and income levels of the participants. 


\subsubsection{Positive Psychological Capital Scale}

The Positive Psychological Capital Scale developed by Tösten (2015) is a scale with 26 items aimed at measuring perceptions of teachers' positive psychological capital. The scale consists of 6 sub-dimensions as self-efficacy, optimism, trust, extroversion, psychological endurance and hope and prepared as 5 likert type (5 = Totally Participating, $4=$ Mostly Participating, $3=$ Undecided, $2=$ Little Participation and 1 = Never Participating). Firstly, the explanatory factor analysis was performed to examine the validity of the structure; and secondly, the confirmatory factor analysis was applied to test the appropriateness of the model identified in the exploratory factor analysis. The variance explained in 6 dimensions on the scale was found to be $61.6 \%$ in total. The compliance indexes of the model in the DFA for the measuring instrument were examined and Chi-square value $(\mathrm{x} 2=728.83, \mathrm{~N}=308, \mathrm{sd}=285, \mathrm{p}=0.00$ ) was found to be significant. Compliance index values were calculated as: RMSEA; 0.071, SRMR; 0.13, GFI; 0.85, AGFI; 0.81, CFI; 0.96, IFI; 0.96, NFI; 0.93; K2 / df = 2.56. Accordingly, it can be said that the model is well adapted and acceptable. The alpha internal consistency coefficient calculated for the scores obtained from the six-dimensional scale were. 79 for the first dimension,. 80 for the second dimension,. 82 for the third dimension, .79 for the fourth dimension,. 75 for the fifth dimension, and.72 for the sixth dimension. The alpha coherence coefficient for the six-dimensional scale was. 92

\subsubsection{Professional Life Quality Scale (PRQ)}

The Professional Life Quality Scale, developed by Erdem (2008), consists of 43 items. The scale was prepared in seven dimensions as; Social security "," social integration "," democratic environment "," fair and equitable response "," total living space "," safe and healthy working conditions "," development of occupational capacity "," social responsibility" in order for teachers to measure the PRQ.

The expert opinion (among the members in the field of measurement and evaluation, education management) was taken for the scope validity of the scale. The scale, which was re-organized according to the opinions received from the experts, has been presented to the opinions of some teachers in terms of comprehensibility. Considering these views, the final form of the scale was prepared. Professional Life Quality Scale was prepared on likert type in five grading. The scale consisted of the options as; (1) never agreeing, (2) little agreeing, (3) moderately agreeing, (4) very agreeing, (5) fully agreeing. As a result of the factor analysis of the PRQ scale, the KMO values were found at least as;:72, the highest as;.89 in the subscales of the professional Life Quality Scale. It can be said that this data set was "very good" for factor analysis. Structural validity of the scale was examined using the Principal Component Analysis technique. The items of factor load values below.45 and the items with high load values in both factors were subtracted from the scale. As a result of the analysis of the basic components of the subscales, it was found out that the lowest factor load values of the items as; .56 the highest as.88. It was found out that the single factor explained $53 \%$ at least, $67 \%$ at most of the total variance. The alpha internal consistency coefficient calculated for the reliability of the total habitat scale was calculated as. 84 at least,.88 at most. This demonstrated that the reliability of the scale and the distinctive powers of the materials were quite high.

\subsection{Data Analysis}

The researcher did the evaluation of the data manually. The obtained data were transferred to these schedules by creating information-processing coding schedules. These data were transferred to the SPSS 22 statistical package program and analysed by appropriate statistical techniques. Statistical techniques such as "?" and "?" were used in the analysis of the data. The results were tested at $\mathrm{p}<0.05$ significance level.

\section{Findings}

In this study, the relationship between teachers' profession life qualities and positive psychological capital levels were investigated. In this part of the study, some findings were stated related to the teachers' profession life qualities and positive psychological capital levels through the frequency and arithmetic mean using the SPSS package program and the relationship between the profession life qualities and positive psychological capital obtained from correlation analysis and regression analysis. The findings related to the research were presented below. 
Table 2 . The profession life quality levels of teachers

\begin{tabular}{|c|c|c|c|}
\hline Levels Of Profession Life Quality & $\mathrm{N}$ & $\bar{X}$ & Ss \\
\hline \multicolumn{4}{|l|}{ Total living space } \\
\hline 1. I am satisfied with my life. & 182 & 3.84 & 1.06 \\
\hline 2. If I came back to the world again, I would not change anything in my life. & 182 & 2.69 & 1.16 \\
\hline 3. My life resembles to my ideal. & 182 & 3.20 & 1.09 \\
\hline 4. I got the important things I want in my life. & 182 & 3.52 & 1.04 \\
\hline Total & 182 & 3.31 & 1.08 \\
\hline \multicolumn{4}{|l|}{ Safe and healthy working conditions } \\
\hline 5. This school is warm enough. & 182 & 3.70 & 1.25 \\
\hline 6. The number of classrooms in this school is sufficient for education and training. & 182 & 3.39 & 1.29 \\
\hline 7. This school has enough physical equipment in terms of social and cultural activities. & 182 & 2.76 & 1.17 \\
\hline 8. This school has enough physical equipment for sports activities. & 182 & 2.49 & 1.16 \\
\hline 9. The working conditions in this school are suitable for health. & 182 & 3.37 & 1.06 \\
\hline 10. This school has a suitable environment for teaching and learning activities. & 182 & 3.49 & 0.97 \\
\hline 11. I feel safe in this school. & 182 & 3.75 & 1.02 \\
\hline Total & 182 & 3.28 & 1.13 \\
\hline \multicolumn{4}{|l|}{ Development of Worker Capacity } \\
\hline 12. It is easy to make a career in this school. & 182 & 3.44 & 1.09 \\
\hline 13. I can use my talents at the highest level in this school. & 182 & 3.02 & 1.03 \\
\hline 14. I can get help and contributions from the managers about work. & 182 & 3.64 & 1.00 \\
\hline 15. I can get help and contributions from the inspectors. & 182 & 2.81 & 1.09 \\
\hline 16. This school provides opportunities to follow changes and innovations related to work. & 182 & 3.32 & 0.95 \\
\hline $\begin{array}{l}\text { 17. Participation in development opportunities as; open-session, conference, panel, etc } \\
\text { school. }\end{array}$ & $\mathrm{s}_{182}$ & 2.89 & 1.02 \\
\hline Total & 182 & 3.19 & 1.03 \\
\hline \multicolumn{4}{|l|}{ Social responsibility } \\
\hline 18. This school organizes art and cultural events for the surrounding. & 182 & 3.02 & 1.04 \\
\hline 19. Activities related to planting the environment are organized in this school. & 182 & 3.09 & 1.03 \\
\hline 20. Great importance is given to the clean surrounding. & 182 & 3.53 & 0.95 \\
\hline 21. There is the mentality of explanation for the actions in this school. & 182 & 3.05 & 1.02 \\
\hline 22. Parental opinions should be taken into consideration in this school. & 182 & 3.66 & 0.91 \\
\hline 23. Equal service is offered to all the members in this school. & 182 & 3.62 & 1.00 \\
\hline 24. This school contributes to community development. & 182 & 3.49 & 1.03 \\
\hline Total & 182 & 3.35 & 0.99 \\
\hline \multicolumn{4}{|l|}{ Social Integration } \\
\hline 25. In this school, managers work in cooperation with teachers. & 182 & 3.68 & 1.02 \\
\hline 26. Everyone trusts each other in this school. & 182 & 3.38 & 1.00 \\
\hline 27. I feel I belong to this school. & 182 & 3.52 & 1.10 \\
\hline 28. My relationships with my supervisors are good. & 182 & 3.94 & 0.89 \\
\hline 29. My relationships with colleagues are good. & 182 & 4.13 & 0.84 \\
\hline Total & 182 & 3.73 & 0.97 \\
\hline \multicolumn{4}{|l|}{ Democratic Environment } \\
\hline 30. I have the chance to make decisions about my work in this school. & 182 & 3.87 & 0.85 \\
\hline 31. I am treated equally by my administrators. & 182 & 3.84 & 0.93 \\
\hline 32. I know my rights and responsibilities. & 182 & 4.17 & 0.82 \\
\hline 33. I can freely defend my rights in this school. & 182 & 3.87 & 0.94 \\
\hline 34. I can talk directly with my superiors directly about the problems related to my work. & 182 & 3.96 & 0.93 \\
\hline 35. The values of the school overlap with my own values. & 182 & 3.63 & 0.98 \\
\hline 36. In this school, managers respect the privacy of private life. & 182 & 3.99 & 0.95 \\
\hline Total & 182 & 3.90 & 0.91 \\
\hline \multicolumn{4}{|l|}{ Appropriate and fair provisions } \\
\hline 37. I think that the salary I get is enough for the work I do. & 182 & 2.66 & 1.33 \\
\hline
\end{tabular}




\begin{tabular}{|c|c|c|c|}
\hline 38. The salary I get is enough to get the academic publications such as books and magazines related to my field. & 182 & 2.64 & 1.12 \\
\hline 39. I have sufficient opportunities for my health rights. & 182 & 2.94 & 1.17 \\
\hline 40. I have sufficient opportunities for the retirement rights. & 182 & 2.22 & 1.14 \\
\hline 41. I have sufficient possibilities for my personal rights. & 182 & 2.52 & 1.12 \\
\hline 42. The salary I get has a positive effect on my productivity. & 182 & 2.64 & 1.20 \\
\hline 43. The salary I get affects my commitment to work positively. & 182 & 2.63 & 1.18 \\
\hline Total & 182 & 2.61 & 1.18 \\
\hline General total & 182 & 3.34 & 1.04 \\
\hline
\end{tabular}

When the mean and standard deviation values of teachers' levels of work quality of life were analysed, it was noticed that the teachers' professional life quality items were mostly participated at "I agree, $(\bar{X}=3.34)$ " level. The item, among the professional life quality, which the teachers attained with the highest average $(\bar{X}=4.17)$, was the expression: "I know my rights and responsibilities". The expression; "I think the possibilities for retirement rights are sufficient", had the lowest average with $(\bar{X}=2.22)$. When the sub-dimensions of Profession life quality were examined, it was seen that teachers participated at the level of "undecided, $\bar{X}=3.31$ " for the total living space sub-dimensions. The item teachers $(\bar{X}=3.84)$ most agreed, related to the total living space, was the expression "pleased from my life". Related to the total living area, teachers had the lowest mean ( $\bar{X}=$ 2.69) of the statement, "If I come back to the world, I would not change anything in my life". Related to the sub-dimension of safe and healthy working conditions, it was noticed that teachers agreed with the expression with "undecided, $\bar{X}=3.28$ " level. It has been observed that teachers agreed with the expression; "I feel safe in this school" with the highest average $(\bar{X}=3.75)$, with the lowest average $(\bar{X}=2.49)$, "This school has enough physical equipment for sports activities".

When the average related to the sub-dimension of the worker capacity development considered, it was noticed that the teachers agreed this dimension with the level of "undecided, $(\bar{X}=3,19)$. When average for this dimension were analysed, it was noticed that the expression which the teachers agreed with the highest average $(\bar{X}=3.44)$ was "It is easy to make a career in this school", and the expression with the lowest average $(\bar{X}=2.81)$ was "I can get help and contributions from the inspectors about my work".

When the averages related to the sub-dimension of social responsibility were taken into consideration, the teachers expressed that they agreed at the level of "undecided, $\bar{X}=3.35$ ". The expression, which the teachers agreed with the highest average in the dimension of social responsibility $(\bar{X}=3.66)$, was "In this school the views of the parents are taken into consideration", the expression with the lowest average $(\bar{X}=3.02)$ was the expression "This school organizes art and cultural activities for the surrounding".

Related to the dimension of social integration, it was observed that teachers agreed with "Agree, $\bar{X}=3.73$ " level. The expression, which the teachers applied related to this sub-dimension, with the highest average $(\bar{X}=$ 4.13) was "My relationships with my colleagues are good", the expression with the lowest average $(\bar{X}=3.38)$ was; "Everyone trusts each other in this school".

Related to the sub-dimension of the democratic environment, it was observed that the teachers agreed with the level of "I agree, $\bar{X}=3.90$ ". The highest average of the expression that the teachers agreed related to the sub-dimension of the democratic environment with the level of $(\bar{X}=4.17)$ was "I know my rights and responsibilities", the lowest average with $(\bar{X}=3.63)$ was the expression "The values of the school overlap with my own values".

Teachers claimed that they agreed with the "undecided, $\bar{X}=2.61$ " level for the appropriate and fair response sub-dimension. Related to this sub-dimension, it was observed that the expression teachers used with the highest average $(\bar{X}=2.94)$, was "I have sufficient opportunities for my health rights", the expression with the lowest average ( $\bar{X}=2.22$ ) was; "I have sufficient opportunities for retirement rights".

Generally speaking, the highest average of the sub-dimensions of the teachers' profession life quality with $(\bar{X}$ $=3.90$ ) was, "democratic environment" sub-dimension, with the lowest average $(\bar{X}=2.61)$ was "appropriate and fair provisions". The averages related to the other sub-dimensions existed orderly as; "social integration dimension" $(\bar{X}=3,73)$, "social responsibility" $(\bar{X}=3.35)$, "total living space" $(\bar{X}=3.31)$, "Safe and healthy working conditions" $(\bar{X}=3.28)$, "development of worker capacity" ( $\bar{X}=3.19)$. 
Table 3. Positive psychological capital levels of teachers

\begin{tabular}{|c|c|c|c|}
\hline Positive Psychological Capital & $\mathbf{N}$ & $\bar{X}$ & Ss \\
\hline \multicolumn{4}{|l|}{ Self-efficacy } \\
\hline I am confident at all stages of my work. & 182 & 4.18 & .73 \\
\hline I have self-confidence. & 182 & 4.31 & .72 \\
\hline I know what I have to do to succeed. & 182 & 4.37 & .64 \\
\hline I know who I am going to get help with the works forcing me. & 182 & 4.20 & .75 \\
\hline Total & 182 & 4.26 & 0.71 \\
\hline \multicolumn{4}{|l|}{ Optimism } \\
\hline I'm a person full of life. & 182 & 3.89 & .95 \\
\hline I am full of energy. & 182 & 3.83 & .98 \\
\hline Life is good. & 182 & 4.08 & .97 \\
\hline I am cheerful. & 182 & 4.05 & .94 \\
\hline Living in the society gives makes me feel in peace. & 182 & 4.04 & 1.02 \\
\hline Total & 182 & 3.98 & 0.97 \\
\hline \multicolumn{4}{|l|}{ Confidence } \\
\hline I am aware of my professional responsibilities. & 182 & 4.45 & .71 \\
\hline I am eager to solve the problems of my students. & 182 & 4.25 & .73 \\
\hline They say I am a efficient in my profession. & 182 & 4.31 & .79 \\
\hline I can account for every work I do. & 182 & 4.47 & .73 \\
\hline Total & 182 & 4.37 & 0.74 \\
\hline \multicolumn{4}{|l|}{ Extroversion } \\
\hline I can inform a group about my profession if it is desired. & 182 & 4.27 & .84 \\
\hline If there is a problem in my school, I can meet with all the municipalities if necessary for solution. & 182 & 4.07 & .89 \\
\hline I can develop new ideas for my school. & 182 & 4.01 & .77 \\
\hline I can represent the institution on professional issues. & 182 & 4.07 & .81 \\
\hline I prefer to be transparent in my professional life. & 182 & 4.29 & .76 \\
\hline Total & 182 & 4.14 & $\mathbf{0 . 8 1}$ \\
\hline \multicolumn{4}{|l|}{ Psychological Resistance } \\
\hline I can deal with the negative events around for the education of my students. & 182 & 4.19 & .76 \\
\hline I make resolving contributions to a problem in my institution. & 182 & 4.19 & .77 \\
\hline I can give solutions to unexpected problems. & 182 & 3.97 & .83 \\
\hline Difficulties increase my challenges to resolve. & 182 & 3.97 & .85 \\
\hline I can fight against difficulties. & 182 & 4.13 & .76 \\
\hline Total & 182 & 4.09 & $\mathbf{0 . 7 9}$ \\
\hline \multicolumn{4}{|l|}{ Hope } \\
\hline The problems I'm experiencing mature me. & 182 & 4.19 & .81 \\
\hline I can deal with several problems at the same time in my job. & 182 & 4.02 & .87 \\
\hline I can deal with the problems somehow in my professional life. & 182 & 4.20 & .76 \\
\hline Total & 182 & 4.14 & 0.81 \\
\hline General Total & 182 & 4.16 & $\mathbf{0 . 8 0}$ \\
\hline
\end{tabular}

As the Table 3 is analysed, it can be claimed that the positive psychological capital levels of teachers are quite high $(\bar{X}=4.16)$. As it is considered in terms of the sub-dimensions of the positive psychological capital, it can easily be noticed that the sub-dimension with the highest average is "confidence" ( $X=4.37)$, the dimension with the lowest average is "optimism" $(\bar{X}=3.98)$. The averages of the other sub-dimensions are orderly as "self-efficacy" ( $\bar{X}=4.26)$, "hope" ( $\bar{X}=4.16)$, "extroversion" $(\bar{X}=4.14)$, "psychological resistance" $(\bar{X}=4.09)$. The item, which teachers agree on with the highest average among the items related to the positive psychological capital levels was "I can account for every work I do." $(\bar{X}=4.47)$, the item they agree on with the lowest average is "I am full of energy." ( $\bar{X}=3.83)$. As it is analysed in terms of the sub-dimensions, the item, which the teachers agree on with the highest average related to the sub-dimension of "self-efficacy" is "I know what I have to do to succeed." $(\bar{X}=4.37)$, the item with the lowest average is "I am confident at all stages of my work." $(\bar{X}=4.18)$. As it is evaluated in terms of the sub-dimension of "optimism", the item with the highest average is "Life is good" ( $\bar{X}=4.08$ ), the lowest average is "I am full of energy". The item that the teachers agree most in the 
sub-dimension of "Confidence" is "I can account for all the work I do" $(\bar{X}=4.47)$, the lowest is "I am eager to solve my students" problems" ( $\bar{X}=4,25)$. The item "I prefer to be transparent in my professional life" within the sub-dimension of "Extroversion" is the item which the teachers agree with the highest average ( $\bar{X}=4.29)$, on the other hand, the item "I can develop new ideas for my school" is the item with the lowest average $(\bar{X}=4.01)$. As it is analysed in terms of the "Psychological resistance", the items with the highest average $(\bar{X}=4.19)$ are "I can deal with the negative events around for the education of my students" and "I make resolving contributions to a problem in my institution", the items with the lowest average are "I can give solutions to unexpected problems" and "Difficulties increases my challenges to resolve". In terms of the sub-dimension of "hope", the item with the highest average is "I can deal with the problems somehow in my professional life." ( $\bar{X}=4.19)$, the item with the lowest average is "I can deal with several problems at the same time in my job".

Table 4. Mean, standard deviation and correlation values of profession life quality and positive psychological capital variables $(\mathrm{N}=182)$

\begin{tabular}{|c|c|c|c|c|c|c|c|c|c|c|c|c|c|c|c|}
\hline & 1 & 2 & 3 & 4 & 5 & 6 & 7 & 8 & 9 & 10 & 11 & 12 & 13 & 14 & 15 \\
\hline 1-PPCS (Total) & 1 & & & & & & & & & & & & & & \\
\hline 2-Self-efficacy & $.815^{* *}$ & 1 & & & & & & & & & & & & & \\
\hline 3-Optimism & $.814 * *$ & $.563 * *$ & 1 & & & & & & & & & & & & \\
\hline 4-Confidence & $.767 * *$ & $.523 * *$ & $.555^{* *}$ & 1 & & & & & & & & & & & \\
\hline 5-Extroversion & $.878 * *$ & $.717 * *$ & $.612 * *$ & $.617 * *$ & 1 & & & & & & & & & & \\
\hline 6-Resistance & $.872 * *$ & $.694 * *$ & $.579 * *$ & $.596 * *$ & $.770 * *$ & 1 & & & & & & & & & \\
\hline 7-Hope & $.737 * *$ & $.557^{* *}$ & $.560 * *$ & $.470 * *$ & $.545^{* *}$ & $.608 * *$ & 1 & & & & & & & & \\
\hline 8-PLQS (Total) & $.558 * *$ & $.345^{* *}$ & $.522 * *$ & $.381 * *$ & $.458 * *$ & $.521 * *$ & $.468 * *$ & 1 & & & & & & & \\
\hline 9-TLA & $.352 * *$ & $.149 *$ & $.424 * *$ & $.219 * *$ & $.249 * *$ & $.309 * *$ & $.323 * *$ & $.615^{* *}$ & 1 & & & & & & \\
\hline 10-SHWC & $.470 * *$ & $.319 * *$ & $.403 * *$ & $.399 * *$ & $.353 * *$ & $.401 * *$ & $.440 * *$ & $.769 * *$ & $.351 * *$ & 1 & & & & & \\
\hline 11-DWC & $.472 * *$ & $.310^{* *}$ & $.483^{* *}$ & $.311 * *$ & $.376^{* *}$ & $.405 * *$ & $.390 * *$ & $.797 * *$ & $.469 * *$ & $.599 * *$ & 1 & & & & \\
\hline 12-SR & $.479 * *$ & $.324 * *$ & $.447 * *$ & $.325^{* *}$ & $.347 * *$ & $.489 * *$ & $.381 * *$ & $.792 * *$ & $.343 * *$ & $.565^{* *}$ & $.666^{* *}$ & 1 & & & \\
\hline 13-SI & $.461^{* *}$ & $.309^{* *}$ & $.395 * *$ & $.294 * *$ & $.415^{* *}$ & $.455^{* *}$ & $.359 * *$ & $.827 * *$ & $.419 * *$ & $.544 * *$ & $.610^{* *}$ & $.679 * *$ & 1 & & \\
\hline 14-DE & $.599 * *$ & $.438 * *$ & $.512 * *$ & $.454 * *$ & $.538 * *$ & $.511 * *$ & $.459 * *$ & $.795^{* *}$ & $.386^{* *}$ & $.568^{* * *}$ & $.570^{* * *}$ & $.597 * *$ & $.771^{* *}$ & 1 & \\
\hline 15-FFP & .127 & .-01 & .133 & .014 & .138 & $.182 *$ & 0.12 & $.611^{* *}$ & $.396^{* *}$ & $.306^{* *}$ & $.312 * *$ & $.316^{* *}$ & $.366^{* *}$ & $.283^{* *}$ & 1 \\
\hline$M$ & 106 & 17 & 19.6 & 16.4 & 20.6 & 20.2 & 12.4 & 143 & 13.4 & 23 & 19.3 & 23.3 & 18.7 & 27 & 18.3 \\
\hline$S D$ & 14.5 & 2.4 & 3.83 & 2.76 & 3.25 & 3.33 & 2.13 & 24.8 & 3.52 & 5.63 & 4.39 & 4.62 & 3.92 & 5.09 & 6.32 \\
\hline
\end{tabular}

Note. PPCS: Positive Psychological Capital Scale, PLQS: Professional Life Quality Scale, TLA: Total Living Area, SHWC: Safe and Healthy Working Conditions, DWC: Developing Worker Capacity, SR: Social Responsibility, SI: Social Integration, DE: Democratic Environment, FFP: Fair and Fair Provision.

** meaningful at the level of $\mathrm{p}<.01$.

$*$ meaningful at the level of $\mathrm{p}<.05$.

As it is observed in the Table 4, it is determined that there is a moderately significant positive correlation between positive psychological capital and professional life quality $(\mathrm{r}=.55, \mathrm{p}<.01)$. It was also observed that the relationship with the highest relationship between the sub-dimensions of the positive psychological capital and profession life quality was determined between the sub-dimensions of positive psychological capital and democratic environment $(\mathrm{r}=.59, \mathrm{p}<.01)$. The lowest relationship between the sub-dimensions of the positive psychological capital and profession life quality was determined between the sub-dimensions of the positive psychological capital and total living area $(\mathrm{r}=.14, \mathrm{p}<.05)$. The highest relationship between the sub-dimensions of the professional life quality and the positive psychological capital was determined between the sub-dimension of optimism of the professional life quality and positive psychological capital $(\mathrm{r}=.522, \mathrm{p}<.01)$. Finally, the lowest relationship between the sub-dimensions of the professional life quality and the positive psychological capital was noticed to be between the self-efficacy sub-dimension of the professional life quality and positive psychological capital $(\mathrm{r}=.34, \mathrm{p}<.01)$.

In the study, it was tried to investigate the predictive power of teachers' work life qualities on positive psychological capital levels. Simple regression analysis was conducted for this purpose, the results are presented in Table 3. 
Table 5. Results of Simple Linear Regression Analysis on the Prediction of Positive Psychological Capital $(\mathrm{N}=182)$

\begin{tabular}{lccccccc}
\hline Variable & $\mathrm{B}$ & Standard error & $\beta$ & $\mathrm{t}$ & $\mathrm{p}$ & binary $\mathrm{r}$ & Partial $\mathrm{r}$ \\
\hline Stable & 59.460 & 5.259 & - & 11.306 & .0001 & - & - \\
\hline Professional Life Quality (Total Score) & .327 & .036 & .558 & 9.013 & .0001 & .558 & .558 \\
\hline $\mathrm{R}=.558$ & $\mathrm{R}^{2}=.311$ & & & & & & \\
\hline $\mathrm{F}_{(1-181)}=81.240$ & $\mathrm{p}=.000$ & & & & & \\
\hline
\end{tabular}

Meaningful at the level of $\mathrm{p}<.01$.

As a result of the simple linear regression analysis conducted to show how teachers' professional life quality predicts positive psychological capital scores, it was observed that there was a significant relationship between the level of their professional life qualities and positive psychological capital scores $\left(\mathrm{R}=.558, \mathrm{R}^{2}=.311\right)$ And the level of professional life quality was found to be a significant predictor of positive psychological capital $\left(F_{(1-181)}=81.240, p<.05\right)$. Professional life quality level explains $31 \%$ of the change in positive psychological capital score. The main predictor variable coefficients of the regression equation $(B=.327)$ test represents that the level of professional life quality is the meaningful predictor $(\mathrm{p}<.05)$. According to the results of the regression analysis, the regression equation that predicts positive psychological capital is as follows.

Positive Psychological Capital Total Score $=(0.327$ x Professional Life Quality Score $)+(59.460)$

\section{Discussion and Result}

In this study, the relationship between the positive psychological capitals of teachers and their professional life qualities were investigated. The results obtained in the research are as follows.

\subsection{The Results Related to the First Sub-Problem}

According to the results obtained from the research, it was found out that the professional life qualities of teachers were determined to be at medium-level (Agree). In the study carried out by Yalçın and Akan (2016), it was also found out that the professional life qualities of teachers were determined to be at medium-level. According to the findings obtained in terms of the sub-dimensions of professional life quality levels of teachers, it was found out that they mostly agreed with the results of the "democratic environment" sub-dimension. Considering this result, it can be expressed that the teachers recognise their school to be in a democratic structure. In the study carried out by Erdem (2008), while the teachers working in the public high schools claimed that they mostly agreed on that there were democratic environments in their schools, the teachers in special high schools expressed that they totally agreed on this fact. According to the another finding obtained, the sub-dimension, which the teachers agreed at the lowest average in terms of their professional life qualities, was the appropriate and fair provision sub-dimension. According to this result, it can be claimed that the teachers had negative thoughts related to their salaries and had low satisfaction levels related to their salaries. In the study carried out by Özpolat (2002), it was found out that the teachers had negative thoughts related to their salaries and they were not satisfied with their salaries.

\subsection{The Results Related to the Second Sub-Problem}

According to the obtained results, it was reached to the end that teachers had high positive psychological capital levels. This result overleaps with the results gathered by Tösten (2015). In the studies by Altınkurt, Ertürk, and Yılmaz (2015) and Kelekçi and Yilmaz (2015), it was found out that the positive psychological capital levels of the teachers were high. The positive psychological capital levels of teachers were found to be at medium-level in the sub-dimension of "optimism". In the study carried out by Kaya, Balay, and Demirci (2014), the psychological capital levels of teachers was found to be at medium level in the sub-dimension of "self-efficacy, hope and optimism". According to this result, it can be claimed that the teachers found life good in the sense of optimism but at a lower level than the other judgments in the optimism dimension of their energy. This result overlaps with the results in the study carried out by Tösten (2015). In addition, in a study carried out by Keser (2013) related to the school principals, it was found out that the psychological capitals of the school principals were found to be high. Another result found in the research was that the "confidence" sub-dimension had the highest average compared with the other sub-dimensions in terms of teachers' positive psychological capital. This result also overlaps with the results of the study carried out by Kelekçi and Yilmaz (2015). According to this result, it can be expressed that the teachers had high levels of explaining behaviour related to their profession. 
The high level of confidence of the teachers, high confidence levels among individuals in organizations, can be expressed as a factor that increases both the happiness of the individuals and the quality of the life of the organization, as well as a desirable situation in terms of their positive contributions to their gifts and gifts (Sağlam-Ar1, 2011). In the study carried out by Özler and Yildırım (2015), the result, which shows that the individuals who trust their organizations they are working with, have increasing psychological capital levels.

\subsection{The Results Related to the First Sub-Problem}

According to the results of this study, it was found out that there is a moderately significant relationship between the positive psychological capital of teachers and the quality of work life in the positive direction. Considering this result, it can be expressed that as the quality of teachers' professional life increases, they will have psychologies that are more positive. In the study by Akçay (2012), positive psychological capital has a positive effect on job satisfaction. Another study carried out by Akdoğan and Polatçı (2013) the increase in the psychological capital of workers has a significant impact on the performance of employees. It is observed from the research results that the highest correlation between positive psychological capital and sub-dimensions of quality of professional life is between positive psychological capital and democratic environment sub-dimension. According to this result, it can be expressed that the increase in teachers' positive psychological capital, leads teachers to perceive their schools as more democratic. It was found that the lowest correlation between positive psychological capital and sub-dimensions of professional life quality was between positive psychological capital and total living space sub-dimension. It was found out that the highest correlation between the professional life quality and the sub-dimensions of positive psychological capital was between the quality of work life and the positive sub-dimension of psychological capital. Finally, the lowest correlation between the professional life quality and the sub-dimensions of positive psychological capital was found to be between the professional life quality and the self-efficacy sub-dimension of positive psychological capital.

\subsection{The Results Related to the First Sub-Problem}

As a result of the simple linear regression analysis conducted to show how teachers' professional life quality predicts positive psychological capital scores, it was observed that there was a significant relationship between the level of professional life quality and positive psychological capital scores and the level of professional life quality was a significant predictor of positive psychological capital. The professional life quality accounts for $31 \%$ of the change in positive psychological capital score. The significance test of the key predictor variable to the regression equation also shows that the level of professional life quality is a significant predictor. In the study carried out by Nguyen and Nguyen (2012), the psychological capital has a positive effect on the professional life quality. In the same study, psychological capital was found to be a significant predictor of professional quality and professional performance.

\section{Recommendations}

It is important for the performance of the teachers that the teacher's working conditions should be re-arranged for the teachers' satisfactions. Particularly, it can be expressed that the improvement of teachers' salaries increases the motivation, job satisfaction, and organizational commitment of teachers. Activities such as conferences, seminar, panels, etc. can be organized for the development of teachers' actual capacities. Supportive steps can be taken to promote the participation in such activities. Precautions can be taken for the retirement rights of teachers. Necessary precautions should be taken to increase the professional reputation of the teachers in terms of positive psychological capital and to make the teaching a respectful profession. The school administration process needs to be re-arranged to meet the expectations of teachers. Especially the negative conditions in the schools have to be eliminated. In the study carried out by Mortazavi, Yazdi, and Amini (2012), it was found out that the psychological capital is a factor that emerges professional life quality and increases the professional life quality.

\section{References}

Akçay, V. H. (2011). The relatıonshıp between positıve psychological capıtal and job satısfactıon. Kahramanmaras Sutcu Imam University Faculty of Economics and Administrative Sciences Journal, 2(1), 123-140.

Akdoğan, A., \& Polatçı, S. (2013). The role of work famıly spıllover and psychological well-being on the effect of psychological capital on performance. Ataturk University Of Journal Social Sciences Institute, 17(1), 273-293.

Altınkurt, Y., Ertürk, A., \& Yılmaz, İ. (2015). The Relationship Between Psychological Capital and Burnout Levels of Teachers, Journal of Teacher Education and Educators, 4(2), 166-187. 
Barutçugil, İ. (2004). Strategic human resources management. İstanbul: Kariyer Publishing.

Erdem, M. (2008). Quality of Work Life and Its Relation to Organizational Commitment According to Teachers in Secondary Schools (Unpublished doctoral dissertation). Ankara University Institute of Educational Sciences, Ankara.

Erginer, A. (2003). The nature of business life. In C. Elma, \& K. Demir, (Eds.), Contemporary Approaches in Management. Ankara: Anı Publishing

Erkmen, T., \& Esen, E. (2012). Categorical investigation of researches in psychological capital between 2003-2011 years. Mustafa Kemal University Journal of Social Sciences Institute, 9(19), 89-103.

Erkuş, A., \& Findıkl1, M. (2013). A research on the impact of psychological capital to job satisfaction, job performance and intention to quit, Istanbul University Journal of the School of Business, 42(2), 302-318.

Karasar, N. (2012). Scientific research method (24th ed.). Nobel broadcast distribution. Ankara.

Kaya, A., Balay, R., \& Demirci, Z. (2014). İnvestigation of secondary school teachers' psychological capital levels (Sample of Sanliurfa). Electronic Journal of Social Sciences, 13(8), 47-68.

Kelekçi, H., \& Yılmaz, K. (2015). Relationship between Positive Psychological Capital Efficacy Beliefs of Teachers. Mersin University Journal of the Faculty of Education, 11(3), 992-1007.

Keser, S. (2013). The Comparison of Elementary School Administrators' Authentic Leadership and Psychological Capital Features. Educational Administration: Theory and Practice, 26(1), 1-22.

Luthans, F. (2002), Positive Organizational Behavior: Developing and Managing Psychological Strengths. Academy of Management Executive, 16(1), 57-72. https://doi.org/10.5465/AME.2002.6640181

Mortazavi, S., Shalbaf Yazdi, S. V., \& Amini, A. (2012). The Role of the Psychological Capital on Quality of Work Life and organization performance. Interdisciplinary Journal of Contemporary Research in Business, 4(2), 206-217.

Nguyen, T. D., \& Nguyen, T. T. (2012). Psychological capital, quality of work life, and quality of life of marketers: Evidence from Vietnam. Journal of Macromarketing, 32(1), 87-95. https://doi.org/10.1177/0276146711422065

Özdevecioğlu, M. (2004). İnvestigation of relationship between Organizational legality with organized organizational support. Dokuz Eylül University Journal of Faculty of Economics and Administrative Sciences, 18(2), 113-130.

Özler, N. D. E., \& Yıldırım, H. B. (2015). A case study to define the relatıon between organızatıonal trust and psychological capıtal. Nevsehir Hacı Bektas Veli University Journal of, 5(1), 163-188.

Özpolat, A. (2002). From Sociological Perspective Teacher Profession and Place of Teachers in Society, According to Teacher, Student and Parent Perceptions: Sample of Zonguldak (Unpublished Phd thesis). Istanbul University Social Sciences Institute, İstanbul.

Sağlam-Arı, G. (2011). The Attitudes of Male and Female Managers With Regard to Trust Qualities: A Research on Hypothetical Subordinates. Ataturk University Journal of Social Sciences Institute, 15(1), 105-120.

Tösten, R. (2015). Examination of teachers' perceptıons on positıve psychologıcal capıtal (Ph.D. thesis, Gaziantep University Educational Sciences Institute, Gaziantep).

Tösten, R., \& Özgan, H. (2014). The Scale of Positive Psychological Capital: A Reliability and Validity Study. EKEV Journal of Academy, 59(59), 429-442.

Uğurlu-Kara, A. (2014). Relationship between positive psychological capital and individual performance (Master thesis, Gazi University Social Sciences Institute, Ankara).

Yalçın, S., \& Durdağı, A. (2016). investıgatıon of the relatıonshıp between leadershıp styles of school administrators and teachers' quality work life and their organizational commitment. Electronic Journal of Social Sciences, 15(59), 1138-1156.

Yücetürk, E. E. (2005). On Mobbing: An invisible syndrome that reduces productivity and the quality of the working environment in Turkey (mobbing). Journal of Economics, Business and Finance, 20(231), 97-108. 


\section{Copyrights}

Copyright for this article is retained by the author(s), with first publication rights granted to the journal.

This is an open-access article distributed under the terms and conditions of the Creative Commons Attribution license (http://creativecommons.org/licenses/by/4.0/). 